\title{
ANALISIS DETERMINAN STUNTING MENURUT WILAYAH GEOGRAFI DI INDONESIA TAHUN 2018
}

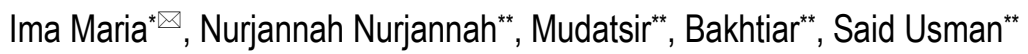

\begin{abstract}
Abstrak
Indonesia memiliki prevalensi stunting sangat tinggi menurut WHO. Indonesia merupakan negara kepulauan terbesar di dunia dengan keanekaragaman suku bangsa. Perbedaan kondisi geografis dan budaya memberikan kontribusi yang berbeda-beda terhadap prevalensi stunting di setiap daerah. Penelitian ini bertujuan untuk menganalisis hubungan antara determinan langsung dan tidak langsung dengan persentase stunting di Indonesia pada tingkat provinsi melalui pendekatan Sistem Informasi Geografis. Data dikumpulkan dari data publik resmi, yang kemudian dilakukan uji korelasi Pearson dan regresi linear berganda. Pemetaan dilakukan dengan menggunakan software ArcGIS 10.7 sehingga dihasilkan peta tematik yang mewakili variabel terikat dan variabel bebas. Hasil meneunjukkan bahwa persentase populasi di bawah kemiskinan $(r=0,431, p=0,011)$, persentase imunisasi dasar lengkap $(r=-0,485, p=0,004)$, persentase ibu hamil dengan tablet tambah darah $(r=-0,341, p=0,048)$, dan rasio puskesmas $(r=-0,439, p$ $=0,009$ ) memiliki hubungan negatif terhadap stunting kecuali kemiskinan. Hasil uji multivariat menunjukkan bahwa cakupan imunisasi dasar lengkap dan rasio puskesmas per kecamatan merupakan faktor determinan yang paling berpengaruh terhadap stunting. Peta tematik yang dihasilkan menunjukkan adanya variasi di setiap provinsi. Studi ini membuktikan bahwa stunting berhubungan dengan banyak faktor. Maka, pemerintah perlu mempertimbangkan faktor determinan yang menjadi karakteristik dari masing-masing provinsi dalam upaya pencegahan stunting, sehingga program pencegahan stunting dapat berjalan dengan maksimal.
\end{abstract}

Kata kunci: determinan, Indonesia, Sistem Informasi Geografis, stunting.

\section{ANALYSIS OF STUNTING DETERMINANTS BASED ON GEOGRAPHIC AREAS IN INDONESIA IN 2018}

\begin{abstract}
Indonesia had a very high stunting prevalence according to WHO classification. Indonesia is largest archipelago country in the world with a wide variety of ethnic groups. Each region has difference determinants of stunting considering the geographical and cultural differences. This study aims to identify the relationship of different determinants (direct and indirect) to the prevalence of stunting in Indonesia at the provincial level using Geographic Information Systems (GIS). The data were retrieved from official public data then analyzed by using Pearson correlation test and multiple linear regression. The mapping is performed by using ArcGIS 10.7 software, so that a thematic map is generated which represents dependent and independent variables. The results indicated that the percent of population below poverty level $(r=$ 0.431, $p=0.011$ ), percent of complete basic immunization $(r=-0.485, p=0.004)$, percent of pregnant women having iron tablets $(r=-0.341, p=0.048)$, and ratio of community health center $(\mathrm{CHC})$ in each subdistrict $(r=-0.439, p=0.009$ ) had negative correlation to stunting, except for poverty. Complete basic immunization coverage and the ratio of $\mathrm{CHC}$ in each subdistrict were the strongest determinants of stunting. Thematic maps showed the determinant variations in each province. This study emphasizes that stunting is related to multiple factors. Therefore, the goverment needs to consider the determinant characteristics of each province in order to enhance stunting prevention programs.
\end{abstract}

Keywords: determinant, Geographic Information Systems, Indonesia, stunting.

*Program Studi Magister Kesehatan Masyarakat, Fakultas Kedokteran, Universitas Syiah Kuala

${ }^{* *}$ Departemen Kesehatan Masyarakat, Fakultas Kedokteran, Universitas Syiah Kuala

凹E-mail: imamaria.md@gmail.com 


\section{Pendahuluan}

Stunting merupakan permasalahan global dan diperkirakan sejumlah 149 juta balita mengalami stunting pada tahun 2018 . Tren stunting secara global memiliki kecenderungan menurun dalam delapan belas tahun terakhir (2000-2018), yakni sebesar 10,6\%.' Begitu pula dengan Indonesia, prevalensi stunting mengalami penurunan hingga $6,4 \%$ pada rentang tahun 2013-2019, namun Indonesia masih termasuk dalam klasifikasi negara dengan prevalensi stunting sangat tinggi (very high) menurut WHO.2,3

Stunting memiliki dampak yang buruk terhadap kualitas sumber daya manusia di masa mendatang, sehingga diperlukan perhatian khusus dalam upaya pencegahan dan penanggulangannya. ${ }^{4-6}$ Intervensi gizi spesifik dan sensitif telah dilakukan oleh pemerintah untuk menekan angka stunting di Indonesia. Namun demikian, skala prioritas diperlukan dalam menyusun program penang-gulangan sehingga mampu mengakomodir keterbatasan sumber daya dan dana. Salah satu metode penyusunan skala prioritas program adalah dengan memetakan potensi masalah di setiap provinsi melalui pendekatan Sistem Informasi Geografis (SIG).

SIG telah banyak digunakan dalam berbagai disiplin ilmu, termasuk bidang kesehatan. ${ }^{7-9}$ Peta yang dihasilkan dari SIG mampu menyajikan informasi hubungan berbagai variabel yang relatif mudah dimengerti secara visual. ${ }^{10}$ Indonesia dengan keanekaragaman kehidupan sosial dan budaya, serta dengan kondisi geografi yang unik, tentu memiliki permasalahan dan determinan stunting yang berbeda di setiap wilayah. Penelitian ini bertujuan untuk melihat hubungan tujuh faktor determinan dengan prevalensi stunting dan mengetahui gambaran faktor determinan di setiap provinsi melalui pendekatan Sistem Informasi Geografis (SIG).

\section{Bahan dan Metode}

Desain Penelitian

Penelitian ini merupakan studi ekologi dengan menggunakan data kelompok yang dilakukan di Fakultas Kedokteran, Universitas Syiah Kuala dan telah mendapatkan persetujuan etik dengan nomor: 1171012P345/EA/FK-RSUDZA/2019.

\section{Sampel Penelitian}

Sampel dari penelitian ini berupa wilayah geografi pada tingkat provinsi. Dengan demikian jumlah sampel adalah 34 provinsi di Indonesia. Data bersumber dari data publik resmi dan dapat diunduh secara daring, yakni Riskesdas 2018, Data dan Informasi Profil Kesehatan Indonesia 2018, dan Data dan Informasi Kemiskinan Kabu-paten/Kota Tahun 2018. $3,11,12$

\section{Variabel Penelitian}

Variabel stunting adalah persentase balita usia 0-59 bulan yang mengalami stunting dan severe stunting. Determinan yang diamati adalah persentase penduduk miskin (\%), cakupan inisiasi menyusui dini (IMD) (\%), cakupan ASI eksklusif (\%), cakupan imunisasi dasar lengkap (IDL) (\%), ibu hamil dengan tablet tambah darah (TTD) (\%), proporsi penduduk merokok (\%), dan rasio puskesmas per kecamatan.

\section{Analisis Statistik}

Uji korelasi Pearson dan regresi linear berganda dilakukan dengan menggunakan IBM SPSS 25. Uji regresi linear dijalankan dengan menggunakan metode backward. Signifikasi yang digunakan adalah $p<0,05$. Asumsi model regresi linear, yakni linearitas, normalitas, homoskedastisitas, dan kolinearitas telah terpenuhi.

\section{Pengolahan Data pada Peta}

Tujuh peta tematik dihasilkan software ArcGIS 10.7 dengan membuat tumpukan lapisan (overlay) dari variabel terikat dan variabel bebas. 
Peta dasar (graduated color map) dibangun dari layer variabel terikat yang diklasifikasikan dalam tiga kelas dengan mengadopsi klasifikasi WHO terbaru. ${ }^{13}$ Graduated symbol map dibangun dari layer variabel bebas dengan metode Manual. Setiap variabel bebas dibagi menjadi dua kelas, sebagai berikut: 1). Persentase penduduk miskin: $\leq 7,5 \%$ (memenuhi target) dan $>7,5 \%$ (tidak memenuhi target), berdasarkan target Rencana Pembangunan Jangka Menengah Nasional 2015-2019.14 2). Cakupan IMD bayi baru lahir: $<47 \%$ (tidak memenuhi target) dan $\geq 47 \%$ (memenuhi target), berdasarkan target Rencana Strategis Program Direktorat Jenderal Bina Gizi dan KIA 2015-2019.15 3). Cakupan ASI eksklusif: <47\% (tidak memenuhi target) dan $\geq 47 \%$ (memenuhi target), berdasarkan target Rencana Strategis Program Direktorat Jenderal Bina Gizi dan KIA 2015-2019.15 4). Cakupan IDL: $<90 \%$ (tidak memenuhi target) dan $\geq 90 \%$ (memenuhi target), berdasarkan target WHO dalam Global Vaccine Action Plan 2011-2020.16 5). Cakupan ibu hamil dengan TTD: $<95 \%$ (tidak memenuhi target) dan $\geq 95 \%$ (memenuhi target), berdasarkan Rencana Strategis
Program Direktorat Jenderal Bina Gizi dan KIA 2015-2019.15 6). Proporsi penduduk merokok: $20-29,9 \%$ (medium), $30-39,9 \%$ (high), dengan mengadopsi dari pelaporan prevalensi merokok menurut WHO.17 7). Rasio puskesmas per kecamatan: $<1$ (tidak cukup) dan $\geq 1$ (cukup), berdasarkan Peraturan Menteri Kesehatan Republik Indonesia Nomor 43 Tahun 2019. ${ }^{18}$

Pembagian kelas untuk setiap variabel bebas bertujuan untuk memudahkan dalam pembacaan peta, serta dapat digunakan untuk menilai keberhasilan program.

\section{Hasil}

Penelitian ini menunjukkan bahwa DKI Jakarta merupakan provinsi dengan prevalensi stunting terendah di Indonesia (Gambar 1), sedangkan 33 provinsi lainnya masuk dalam kategori high (14 provinsi) dan very high (19 provinsi). Cakupan ASI eksklusif dan rasio puskesmas per kecamatan merupakan dua variabel yang sebagian besar provinsi termasuk dalam kelas memenuhi target.

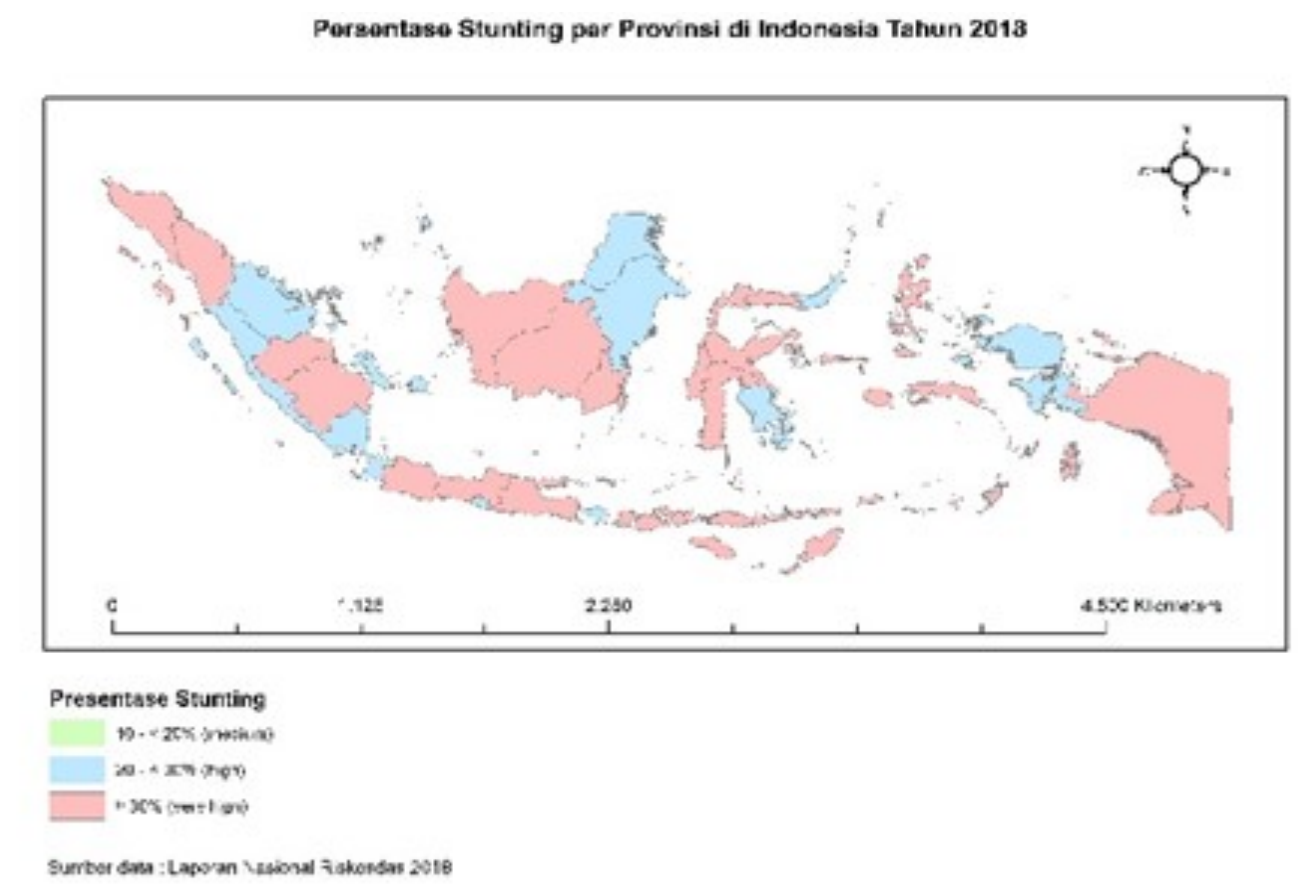

Gambar 1. DKI Jakarta merupakan provinsi dengan prevalensi stunting terendah di Indonesia. 
Pada pemetaan terlihat bahwa DKI Jakarta merupakan provinsi dengan kondisi yang terbaik dengan persentase kemiskinan yang rendah, serta hanya satu determinan yang tidak terpenuhi, yakni imunisasi dasar lengkap. Secara umum, provinsi dengan persentase penduduk miskin $>7,5 \%$ memiliki prevalensi stunting very high. Maluku Utara, Kalimantan Selatan, Kalimantan Tengah, dan Jawa Barat merupakan provinsi dengan prevalensi stunting very high walaupun persentase penduduk miskinnya relatif rendah (Gambar 2).

Papua, Maluku, Maluku Utara, Kalimantan Selatan, dan Sumatera Utara merupakan provinsi dengan prevalensi stunting very high yang tidak menuhi taget cakupan IMD, sedangkan Papua Barat, Sulawesi Tenggara, dan Bali merupakan provinsi yang tidak memenuhi target cakupan IMD dengan

Persentase Penduduk Miskin terhadap Stunting per Provinsi di Indonesia Tahun 2018
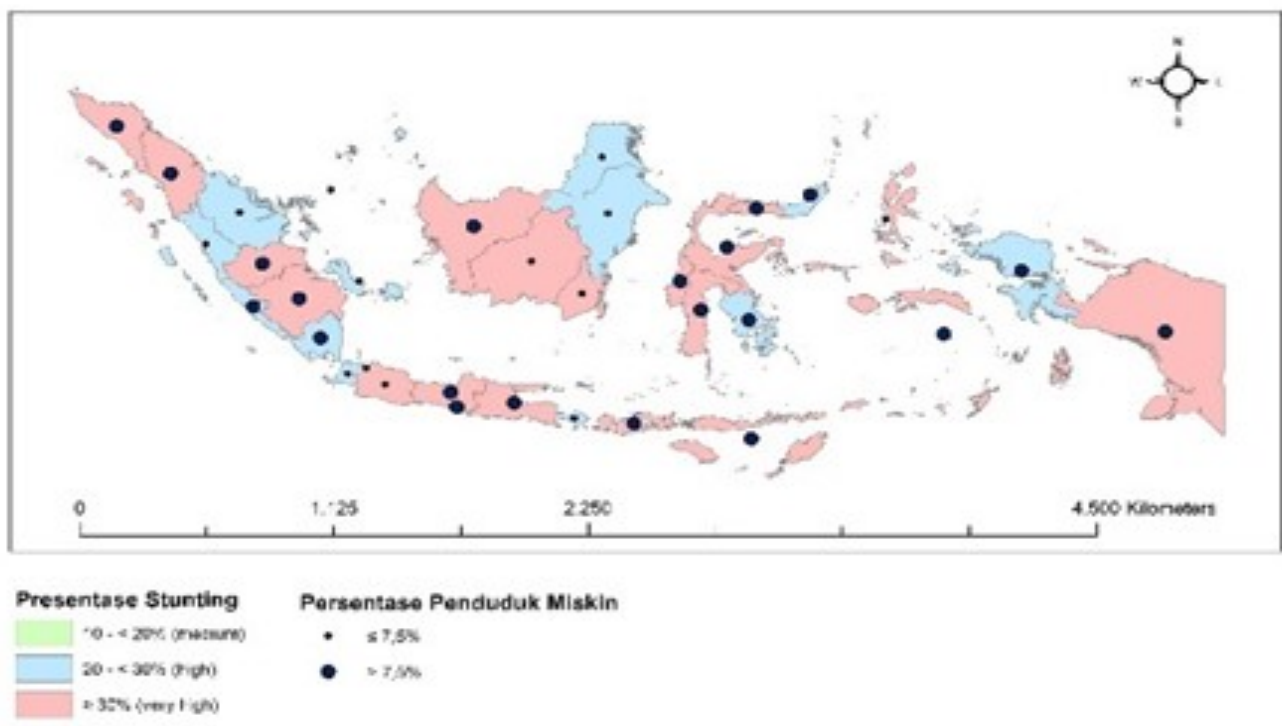

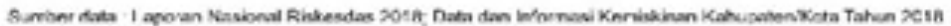

Gambar 2. Persentase penduduk miskin di Indonesia tahun 2018.

Cakupan IMD Bayi Baru Lahir terhadap Stunting por Provinsi di Indonesia Tahun 2018
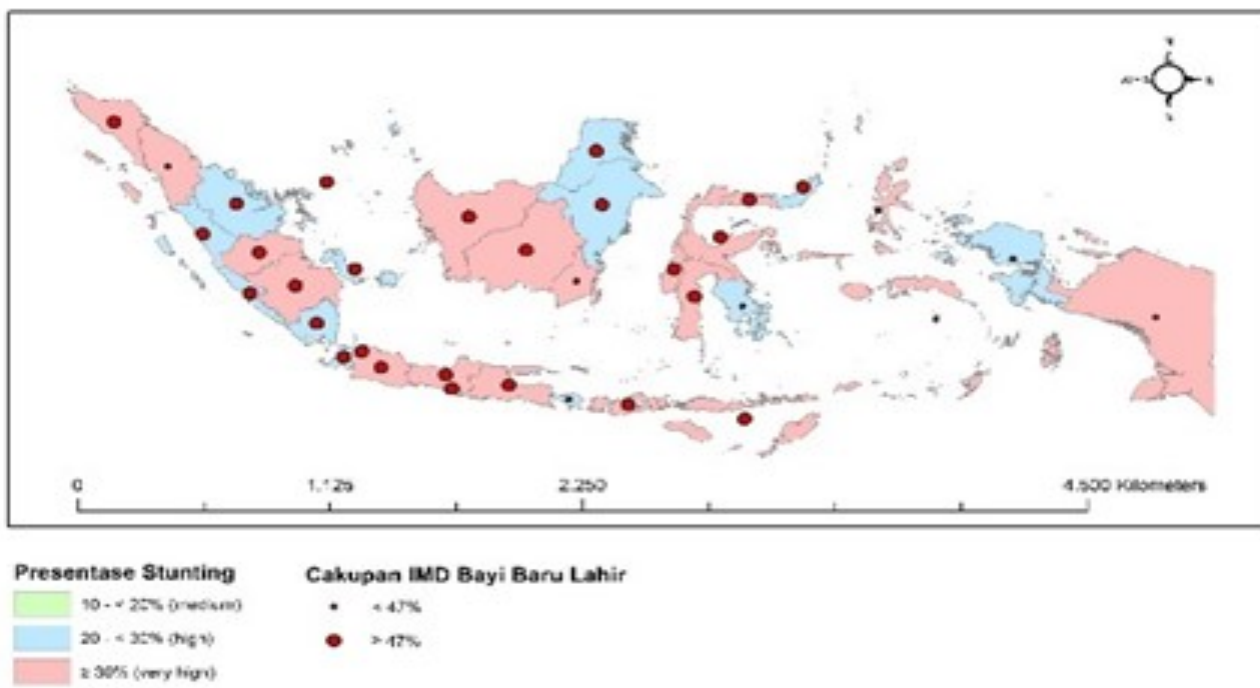

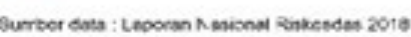

Gambar 3. Cakupan IMD bayi baru lahir di Indonesia tahun 2018. 
Papua Barat, Maluku, Gorontalo, dan Su- merupakan satu-satunya provinsi yang memelawesi Utara merupakan provinsi yang tidak nuhi target cakupan IDL menurut WHO. memenuhi target nasional untuk cakupan ASI Bengkulu (stunting high) dan DKI Jakarta eksklusif. Maluku dan Gorontalo memiliki pre- (stunting medium) adalah dua provinsi yang valensi stunting very high, sedangkan Papua memenuhi target cakupan ibu hamil dengan Barat dan Sulawesi Utara merupakan provinsi TTD $\geq 95 \%$, sedangkan seluruh provinsi dengan dengan prevalensi stunting high (Gambar 4). $\quad$ prevalensi very high tidak berhasil memenuhi

Pada Gambar 5 menunjukkan bahwa Pro- target tersebut (Gambar 6).

vinsi Bali dengan prevalensi stunting high

Cakupan ASI Eksklusif terhadap Stunting por Provinsi di Indonesia Tahun 2018
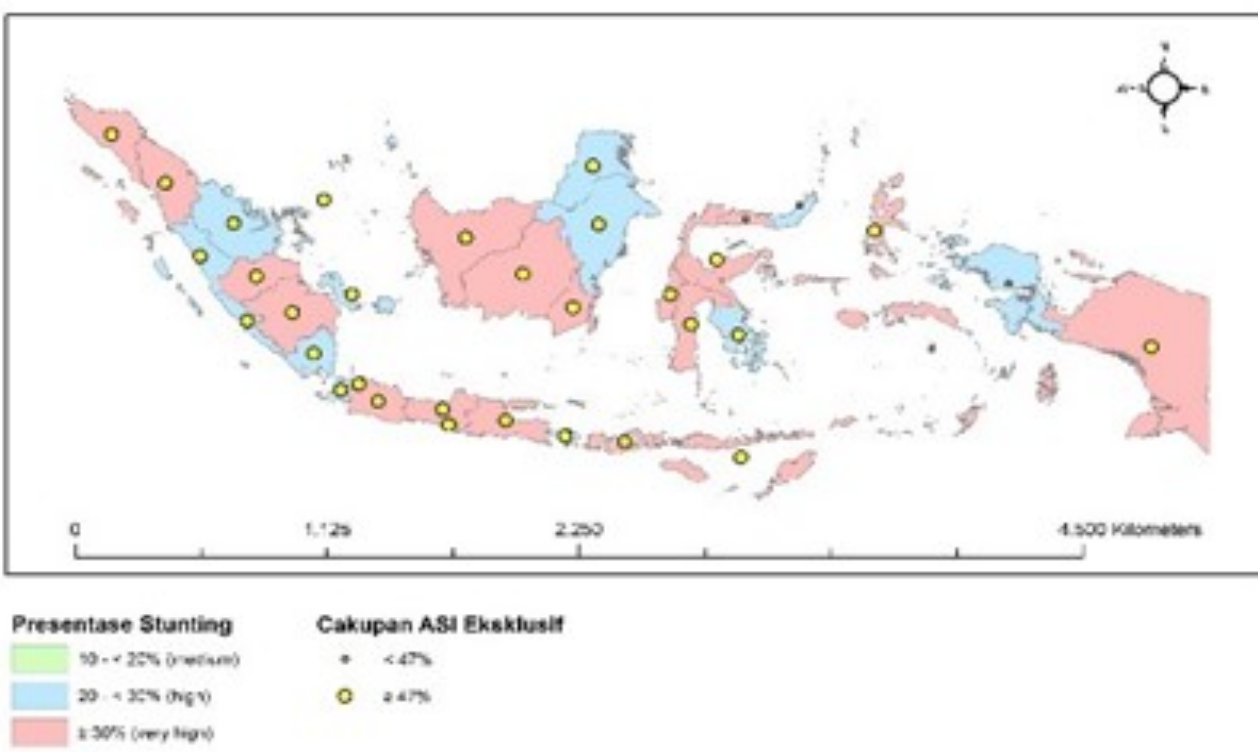

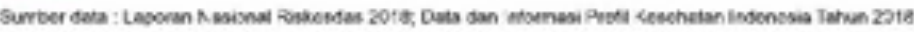

Gambar 4. Cakupan ASI eksklusif di Indonesia tahun 2018.

Cakupan Imunisasi Dasar Lengkap terhadap Stunting per Provinsi di Indonesia Tahun 2018
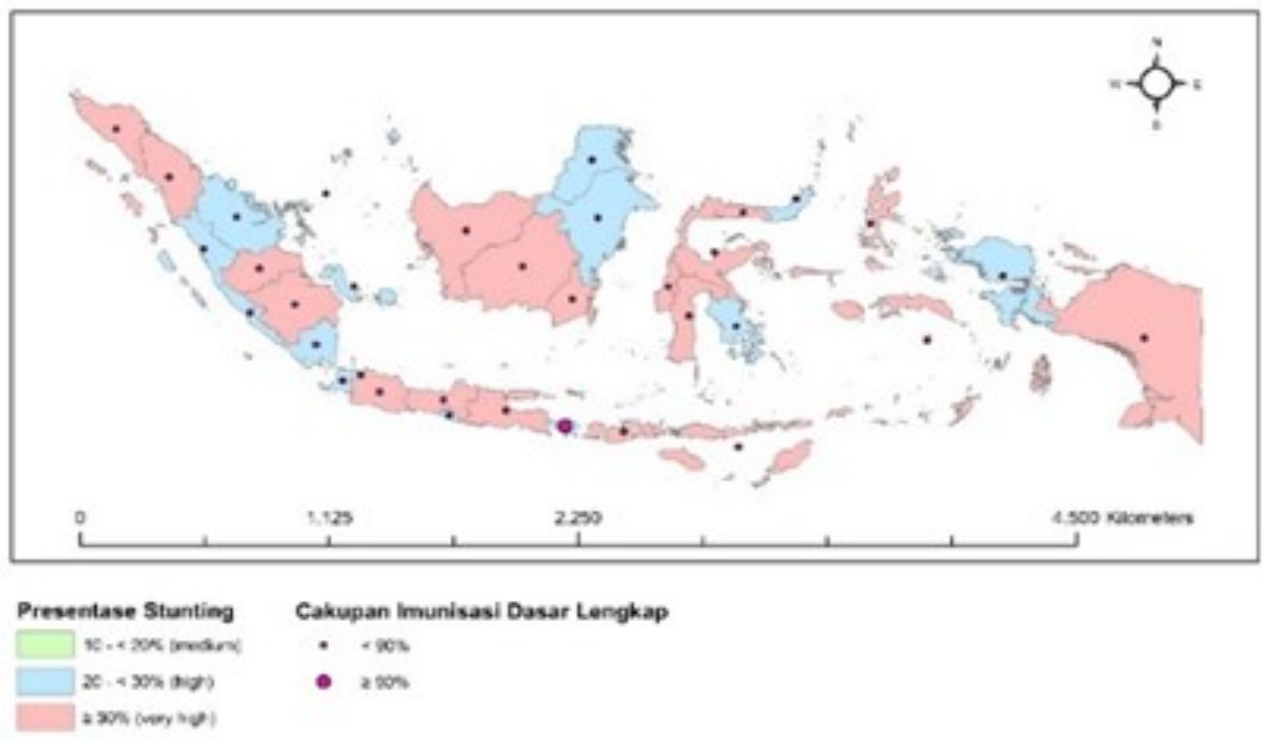

Sumber dra : Laverm vaseona Resiences 2016

Gambar 5. Cakupan imunisasi dasar lengkap di Indonesia tahun 2018. 

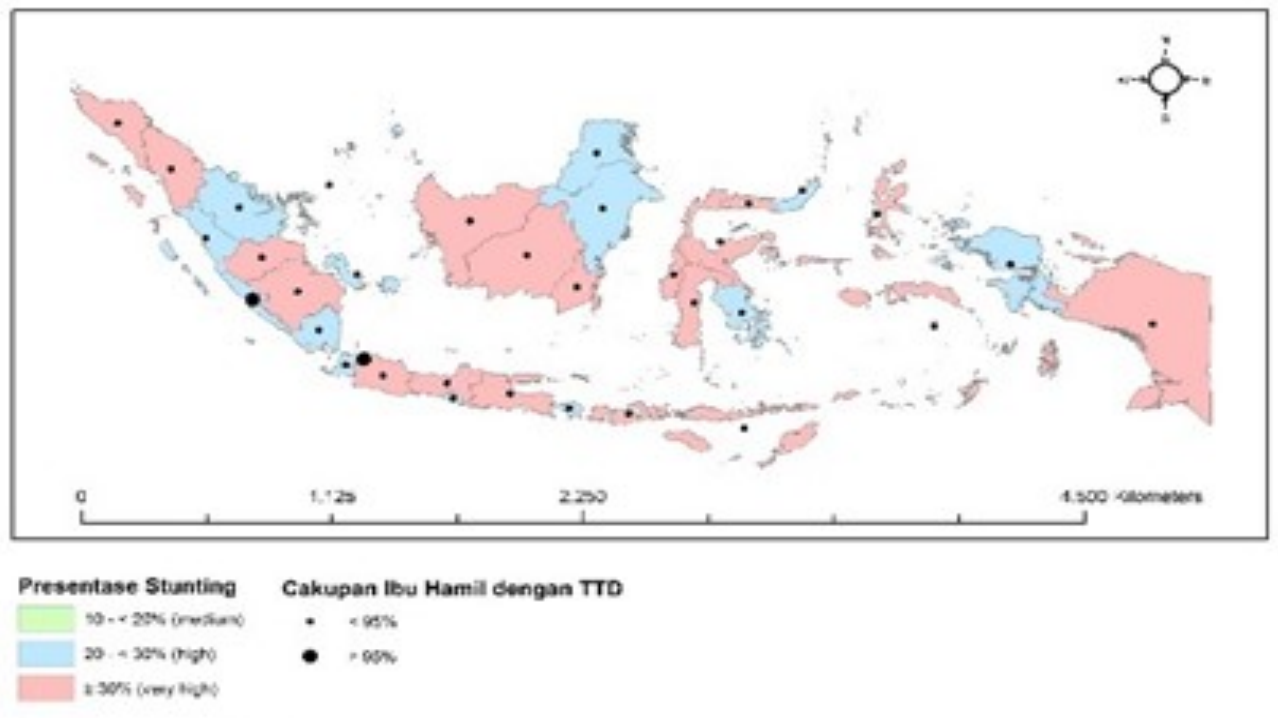

Sumber deta : Lecoran Nancona Resicesdes 2010

Gambar 6. Cakupan ibu hamil dengan TTD di Indonesia tahun 2018.

Rasio Puskesmas per Kecamatan terhadap Stunting per Provinsi di Indonesia Tahun 2018
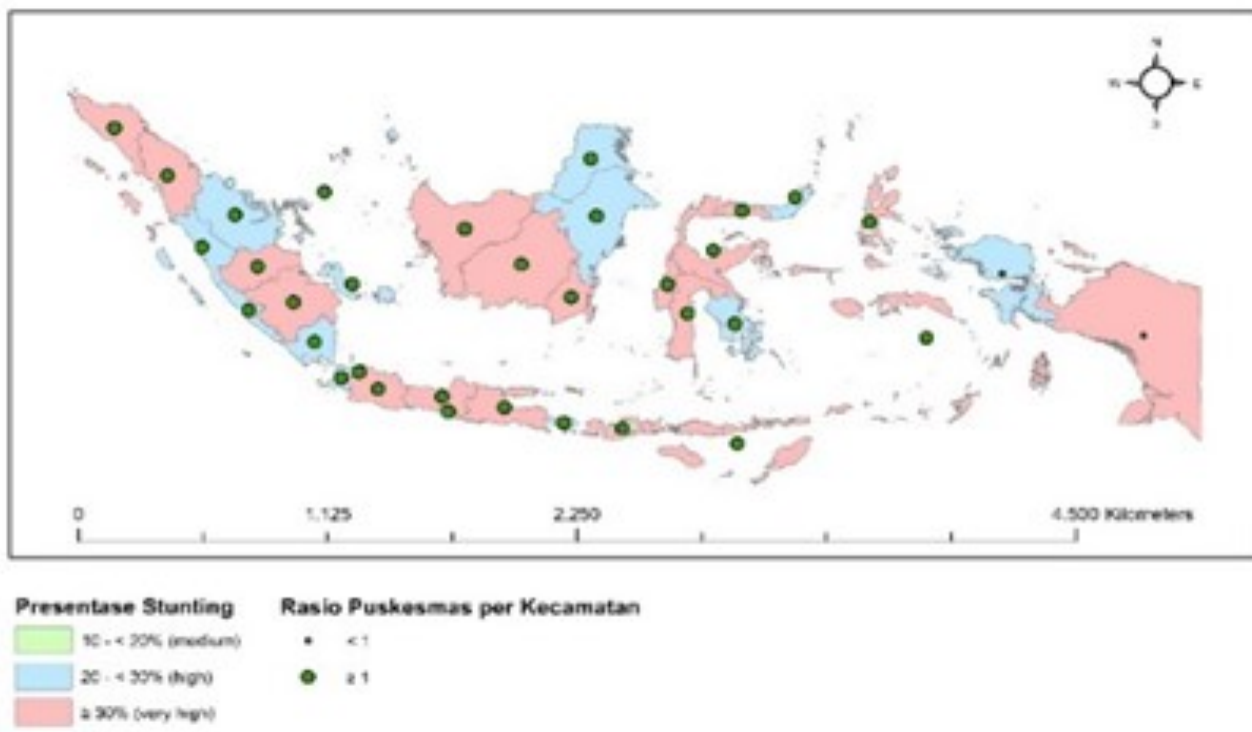

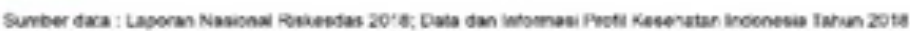

Gambar 7. Rasio puskesmas di Indonesia tahun 2018.

Pada Gambar 7 menunjukkan bahwa rasio kecukupan puskesmas tidak dimiliki oleh Papua dan Papua Barat. Papua memiliki prevalensi stunting very high, sedangkan provinsi Papua Barat memiliki status prevalensi stunting high.

Pada provinsi dengan prevalensi stunting very high, proporsi penduduk merokok yang besar adalah Jawa Barat, Nusa Tenggara Barat, Sulawesi Tengah, dan Gorontalo. Sedangkan provinsi dengan prevalensi stunting high, proporsi penduduk merokok yang besar adalah Sumatera Barat, Bengkulu, Lampung dan Banten (Gambar 8). 

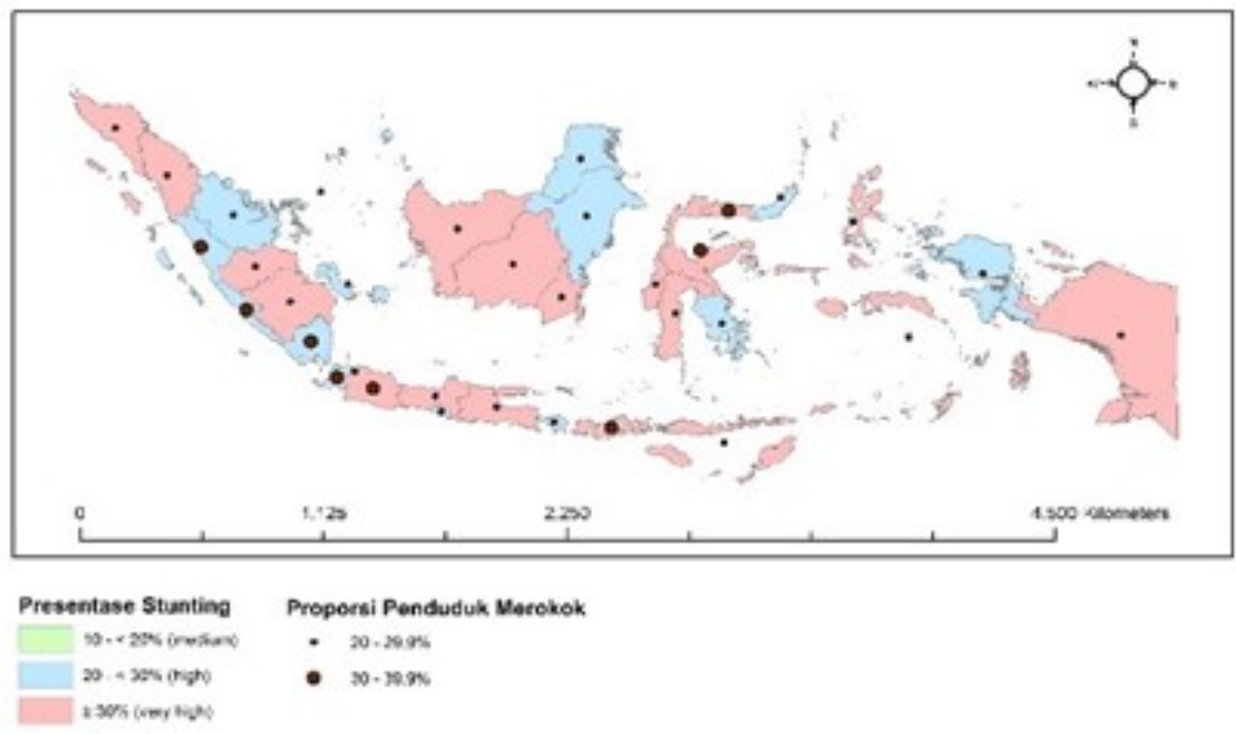

Sumber deta : Lacoran Nasions: Resicesdes 2010

Gambar 8. Proporsi penduduk merokok di Indonesia tahun 2018.

Tabel 1. Model regresi

\begin{tabular}{|c|c|c|c|c|c|c|}
\hline & \multirow{2}{*}{$\beta$} & \multirow{2}{*}{ SE of $\beta$} & \multicolumn{2}{|c|}{$95 \% \mathrm{Cl}$ for $\beta$} & \multirow{2}{*}{$\begin{array}{l}\text { Koefisien } \\
\text { korelasi }\end{array}$} & \multirow{2}{*}{$p$ value } \\
\hline & & & Upper & Lower & & \\
\hline Konstanta & 40,160 & 2,727 & 34,598 & 45,722 & & $<0,001^{*}$ \\
\hline Imunisasi dasar lengkap & $-0,128$ & 0,047 & $-0,223$ & $-0,033$ & $-0,407$ & 0,010 \\
\hline $\begin{array}{l}\text { Rasio puskesmas per } \\
\text { kecamatan }\end{array}$ & $-1,755$ & 0,750 & $-3,283$ & $-0,226$ & $-0,348$ & 0,026 \\
\hline
\end{tabular}

Keterangan: * signifikan jika $p$ value $<0,005$

Hasil uji korelasi Pearson menunjukkan bahwa terdapat korelasi negatif yang signifikan antara stunting terhadap cakupan IDL $(r=-0,485, p=0,004)$, persentase ibu hamil dengan $\operatorname{TTD}(r=-0,341, p=0,048)$, dan rasio puskesmas per kecamatan $(r=-0,439, p$ $=0,009)$. Persentase penduduk miskin berkorelasi positif terhadap stunting $(r=$ $0,431, p=0,011)$. Hal ini menunjukkan bahwa semakin tinggi kemiskinan, maka semakin tinggi prevalensi stunting. Sementara itu, inisiasi menyusui dini $(r=-0,205, p=0,245)$, pemberian ASI eksklusif $(r=0,112, p=$ $0,528)$, dan proporsi penduduk merokok tidak berkorelasi dengan stunting $(r=-0,005, p=$ 0,975).
Hasil uji regresi linear dengan metode backward menunjukkan bahwa cakupan IDL $(p=0,010)$ dan rasio puskesmas per kecamatan $(p=0,026)$ merupakan dua prediktor yang signifikan. Berdasarkan pada Tabel 1, maka dapat disusun rumus prediksi dari uji regresi linear berganda $(F(2,31)=$ $8,374, p<0,001$ ) dengan $R^{2}=0,350$. Prediksi prevalensi stunting dapat dihitung dengan 40,160-0,128 (cakupan imunisasi dasar lengkap) -1,755 (rasio puskesmas per kecamatan). Prevalensi stunting akan menurun sebesar 0,128 persen untuk setiap persen kenaikan dari cakupan IDL dan menurun sebesar 1,755 untuk setiap penambahan jumlah puskesmas di setiap kecamatan. 


\section{Pembahasan}

Kemampuan konsumsi menu yang bervariasi dalam jumlah yang optimal berkaitan erat dengan kemiskinan. ${ }^{19,20}$ Variasi menu merupakan hal yang penting terhadap kecukupan gizi. ${ }^{21}$ Hong menyatakan bahwa stunting lebih rentan dialami oleh anak yang berasal dari keluarga yang miskin. ${ }^{22}$ Sejalan dengan Hong, analisis data dari 79 negara yang dilakukan oleh Black et al. menunjukkan bahwa negara miskin memiliki prevalensi stunting lebih tinggi hampir tiga kali lipat dibandingkan dengan negara yang lebih maju. ${ }^{23}$ Indonesia merupakan negara berpenghasilan menengah ke bawah sehingga prevalensi stunting terendahnya adalah kategori medium. DKI Jakarta sebagai provinsi dengan kemiskinan yang lebih rendah dibandingkan dengan provinsi lain, memungkinkan provinsi tersebut untuk mengkonsumsi sumber protein hewani yang bervariasi. Berdasarkan data Susenas September 2018, Konsumsi protein hewani DKI Jakarta berada jauh di atas rerata konsumsi nasional. ${ }^{24}$ Jawa Barat dan Maluku Utara sebagai provinsi dengan kemiskinan yang juga relatif rendah (prevalensi stunting vey high) ternyata memiliki konsumsi protein hewani di bawah rerata nasional. 24

Kemiskinan juga dikaitkan dengan peningkatan kejadian infeksi pada balita. ${ }^{25}$ Infeksi berulang maupun infeksi kronis yang dialami oleh anak merupakan salah satu faktor risiko stunting. ${ }^{26,27}$ Berdasarkan data Riskesdas 2018, Jawa Barat dan Kalimantan Tengah memiliki persentase penyakit infeksi pada balita di atas rerata nasional. Persentase balita diare, pneumonia, dan ISPA di Jawa Barat berada di atas rerata nasional, sedangkan Kalimantan Tengah memiliki persentase balita pneumonia hingga $11,8 \%{ }^{3}$ Dengan demikian, konsumsi protein hewani yang rendah serta infeksi pada balita yang tinggi, kemungkinan merupakan penyebab prevalensi stunting very high di Maluku Utara,
Kalimantan Tengah, dan Jawa Barat.

Kondisi sanitasi yang kurang baik merupakan penyebab tingginya penyakit infeksi di negera berkembang. ${ }^{28}$ Pemberian imunisasi mampu mengurangi angka kesakitan akibat infeksi, sehingga infeksi berulang yang menyebabkan malnutrisi juga dapat ditekan. ${ }^{29,30}$ Beberapa studi menunjukkan bahwa risiko stunting dapat diturunkan oleh imunisasi. ${ }^{31,32}$

Pada kehamilan terjadi peningkatan kebutuhan zat besi. ${ }^{33}$ Zat besi tersebut berperan terhadap pertumbuhan dan perkembangan janin. ${ }^{34}$ Kehamilan dengan anemia pada trimester satu dan dua, berpotensi melahirkan bayi dengan berat badan lahir rendah (BBLR) dan BBLR merupakan faktor risiko dari stunting. ${ }^{35,36}$ Hasil penelitian ini sesuai dengan studi terdahulu, bahwa pemberian tablet tambah darah pada ibu hamil dapat menurunkan risiko stunting. ${ }^{37}$

Kecukupan jumlah puskesmas dapat digambarkan dari rasio puskesmas per kecamatan sebagai upaya pemenuhan akses terhadap pelayanan kesehatan pada suatu wilayah. ${ }^{38}$ Berbeda dengan hasil penelitian ini, studi terdahulu menyatakan bahwa rasio puskesmas tidak berkaitan dengan stunting.39,40 Dalam kerangka konseptual WHO, terdapat konteks yang secara tidak langsung berhubungan dengan stunting, yakni keberadaan fasilitas pelayanan kesehatan. ${ }^{41}$ Pelayanan kesehatan memiliki tanggung jawab dalam identifikasi permasalahan pertumbuhan dan perkembangan, serta berperan dalam memberikan informasi dan edukasi terhadap stunting. ${ }^{41}$ Komunitas yang mendapatkan edukasi gizi yang baik dari pelayanan kesehatan cenderung memiliki angka stunting yang lebih rendah. ${ }^{42}$

Hasil pemetaan menggambarkan rangkaian determinan yang diteliti di setiap provinsi, sehingga setiap provinsi dapat menyusun prioritas risiko stunting menurut ketercapaian determinan tersebut. 
Cakupan IDL dan rasio puskesmas per kecamatan merupakan determinan yang paling menonjol pada pemetaan. Dengan demikian, hasil pemetaan ini sejalan dengan hasil regresi linear berganda.

Pemberian IMD dan ASI eksklusif, konsumsi TTD pada ibu hamil, serta pemberian imunisasi dasar lengkap merupakan penyebab langsung stunting, sedangkan keberadaan puskesmas, kemiskinan, dan penduduk merokok merupakan bagian dari konteks dalam kerangka konseptual WHO. DKI Jakarta berhasil memenuhi enam variabel dari tujuh variabel yang diteliti. Pencapaian lima variabel dimiliki oleh Kalimantan Tengah, Kalimantan Utara, Kalimantan Timur, Bali, Kepulauan Riau, Bangka Belitung, dan Riau. Semakin banyak variabel yang dicapai, maka semakin rendah prevalensi stunting di setiap provinsi. Namun demikian, hasil pemetaan tidak sejalan dengan dugaan tersebut. Hal ini mungkin disebabkan oleh keberadaan determinan lain yang lebih berperan di setiap provinsi. Oleh karena itu, diperlukan eksplorasi terhadap determinan lain yang merujuk pada kerangka konseptual WHO di setiap provinsi.

\section{Kesimpulan}

Prevalensi stunting very high tersebar secara merata di bagian barat dan bagian timur Indonesia dengan gambaran determinan yang berbeda di setiap provinsi. Pengambil kebijakan perlu mempertimbangkan untuk meningkatkan cakupan imunisasi dasar lengkap dan menambah jumlah puskesmas dalam suatu kecamatan sebagai upaya penanggulangan stunting.

\section{Daftar Pustaka}

1. United Nations Children's Fund (UNICEF), World Health Organization, International Bank for Reconstruction and
Development/The World Bank. Levels and Trends in Child Malnutrition: Key Fndings of the 2019 Edition of the Joint Child Malnutrition Estimates. Geneva. 2019.

2. Badan Penelitian dan Pengembangan Kesehatan. Riskedas 2013 Dalam Angka [Internet]. 2013. Available from: http:// labmandat.litbang.depkes.go.id/images/ download/laporan/RKD/2013/ RKD_dalam_angka_final.pdf

3. Badan Penelitian dan Pengembangan Kesehatan. Laporan Nasional Riset Kesehatan Dasar 2018 [Internet]. Lembaga Penerbit Balitbangkes (LPB). [Internet]. 2019. [cited 2019 Nov 5]. Available from: http:// labdata.litbang.kemkes.go.id/images/ download/laporan/RKD/2018/ Laporan_Nasional_RKD2018_FINAL.pdf

4. Dewey KG, Begum K. Long-Term Consequences of Stunting in Early Life. Matern Child Nutr. [Internet]. 2011; 7:518. Available from: http:// doi.wiley.com/10.1111/j.17408709.2011.00349.x

5. Case A, Paxson C. Causes and Consequences of Early-Life Health. Demography. [Internet]. 2010; 47(S):S6585. Available from: http:// link.springer.com/10.1353/dem.2010.0007

6. Horton S, Steckel RH. Malnutrition: Global Economic Losses Attributable to Malnutrition 1900-2000 and Projections to 2050. In: Lomborg B (Editor). How Much have Global Problems Cost the World?. Cambridge: Cambridge University Press; 2014. p. 247-72. Available from: https:// www.cambridge.org/core/product/identifier/ CB09781139225793A018/type/book_part

7. Caley LM. Using Geographic Information Systems to Design Population-Based Interventions. Public Health Nurs. [Internet]. 2004; 21(6):547-54. Available from: http://doi.wiley.com/10.1111/j.07371209.2004.21607.x. 
8. Cromley EK, McLafferty SL. GIS and Public Health. Guilford Press; 2011.

9. Curtis $A B$, Kothari C, Paul R, Connors E. Using GIS and Secondary Data to Target Diabetes-Related Public Health Efforts. Public Health Rep. [Internet]. 2013; 128 (3):212-20. Available from: http:// journals.s a ge pub.com / doi/10.1177/003335491312800311.

10. Maantay J. Mapping Environmental Injustices: Pitfalls and Potential of Geographic Information Systems in Assessing Environmental Health and Equity. Environ Health Perspect. [Internet]. 2002; 110(suppl 2):161-71. Available from: https://ehp.niehs.nih.gov/ doi/10.1289/ehp.02110s2161

11. Kementrian Kesehatan Republik Indonesia. Data dan Informasi Profil Kesehatan Indonesia 2018 [Internet]. Jakarta; 2019. Available from: https:// www.kemkes.go.id/resources/download/ pusdatin/profil-kesehatan-indonesia/Datadan-Informasi_Profil-KesehatanIndonesia-2018.pdf

12. Badan Pusat Statistik. Data dan Informasi Kemiskinan Kabupaten/Kota 2018 [Internet]. 2019 [cited 2019 Nov 4]. Available from: https://www.bps.go.id/ publication/2019/04/09/169913d55c823a 84 bc52fdb3/data-dan-informasikemiskinan-kabupaten-kota-tahun2018.html

13. De Onis M, Borghi E, Arimond M, Webb $\mathrm{P}$, Croft $\mathrm{T}$, Saha $\mathrm{K}$, et al. Prevalence Thresholds for Wasting, Overweight and STUNting in Children under 5 Years. Public Health Nutr. [Internet]. 2019; 22 (1):175-9.

14. Kementerian Perencanaan Pembangunan Nasional. Rencana Pembangunan Jangka Menengah Nasional 2015-2019. In 2015. Available from: https://www.bappenas.go.id/id/datadan-informasi-utama/dokumenperencanaan-dan-pelaksanaan/dokumen -rencana-pembangunan-nasional/rpjp- 2005-2025/rpjmn-2015-2019/

15. Direktorat Jenderal Bina Gizi dan KIA. Rencana Strategis Program Jendral Bina Gizi dan KIA [Internet]. 2015. Available from: https://www.depkes.go.id/ resources/download/RAP Unit Utama 2015-2019/3. Ditjen Kesmas.pdf

16. WHO. Global Vaccine Action Plan and Decade of Vaccines Review and lessons learned reports. WHO [Internet]. 2019 [cited 2020 Jan 2]; Available from: https:// www. who.int/immunization/ global_vaccine_action_plan/ GVAP_review_lessons_learned/en/

17. World Health Organization. Prevalence of tobacco smoking [Internet]. World Health Organization; 2016 [cited 2019 Nov 25]. Available from: https://www.who.int/gho/ tobacco/use/en/

18. Menteri Kesehatan Republik Indonesia. Peraturan Menteri Kesehatan Republik Indonesia Nomor 43 Tahun 2019 [Internet]. 2019. Available from: https:// www.dinkes.kotabogor.go.id/asset/ images/web/files/pmk-nomor-43-tahun2019-tentang-puskesmas.pdf

19. Darapheak C, Takano T, Kizuki M, Nakamura K, Seino K. Consumption of Animal Source Foods and Dietary Diversity Reduce Stunting in Children in Cambodia. Int Arch Med. [Internet]. 2013; 6(1):29. Available from: http:// www.intarchmed.com/content/6/1/29

20. Rah JH, Akhter N, Semba RD, Pee S de, Bloem MW, Campbell AA, et al. Low Dietary Diversity is a Predictor of Child Stunting in Rural Bangladesh. Eur J Clin Nutr. [Internet]. 2010; 64(12):1393-8. Available from: http://www.nature.com/ articles/ejcn2010171

21. Torheim LE, Ouattara F, Diarra MM, Thiam FD, Barikmo I, Hatløy A, et al. Nutrient Adequacy and Dietary Diversity in Rural Mali: Association and Determinants. Eur J Clin Nut. [Internet]. 2004; 58(4):594-604. Available from: http://www.nature.com/articles/1601853 
22. Hong R. Effect of Economic Inequality on Chronic Childhood Undernutrition in Ghana. Public Health Nutr. [Internet]. 2007; 10(4):371-8. Available from: https:// www.cambridge.org/core/product/ identifier/S1368980007226035/type/ journal_article

23. Black RE, Victora CG, Walker SP, Bhutta $Z A$, Christian $P$, De Onis $M$, et al. Maternal and Child Undernutrition and Overweight in Low-Income and MiddleIncome Countries. Lancet. [Internet]. 2013; 382(9890):427-51.

24. Badan Pusat Statistik. Consumption of Calorie and Protein of Indonesia and Province, September 2018 [Internet]. Jakarta: Badan Pusat Statistik; 2018. Available from: https://www.bps.go.id/ publication/download.html? nrbvfeve=NmMzZTYxMjEwMzY4NTI2NW I

YzQ4MmRj\&xzmn=aHR0cHM6Ly93d3cu YnBzLmdvLmlkL3B1YmxpY2F0aW9uLzl wMTkvMDYvMjgvNmMzZTYxMjEwMzY4 NTI2NWIxYzQ4MmRjL2tvbnN1bXNpLWt hbG9yaS1kYW4tcHJvdGVpbi1wZW5kdW R1ay1pbmRvbmVzaWEtZGFu

25. Caulfield LE, Richard SA, Rivera JA, Musgrove P, Black RE. Stunting, Wasting, and Micronutrient Deficiency Disorders. In: Disease Control Priorities in Developing Countries [Internet]. $2^{\text {nd }}$ Edition. Washington (DC): The International Bank for Reconstruction and Development/The World Bank; 2006 [cited 2019 Apr 29]. Available from: https://www.ncbi.nlm.nih.gov/books/ NBK11761/

26. Prendergast AJ, Humphrey JH. The Stunting Syndrome in Developing Countries. Paediatr Int Child Health. 2014 1; 34(4):250-65.

27. Prendergast AJ, Rukobo S, Chasekwa B, Mutasa K, Ntozini R, Mbuya MNN, et al. Stunting Is Characterized by Chronic Inflammation in Zimbabwean Infants.
John-Stewart GC (Editor). PLOS One. [Internet]. 2014; 9(2):e86928. Available from: https://dx.plos.org/10.1371/ journal.pone.0086928.

28. Mara D, Lane J, Scott B, Trouba D. Sanitation and Health. PLOS Med. [Internet]. 2010; 7(11):e1000363. Available from: https:// $d x . p / o s . o r g / 10.1371 /$ journal.pmed.1000363.

29. Whitney CG, Zhou F, Singleton J, Schuchat $A$. Benefits from Immunization during the Vaccines for Children Program Era - United States, 1994-2013. CDCMorb Mortal Wkly Rep. 2014; 63(16)352355.

30. Bloss E. Prevalence and Predictors of Underweight, Stunting, and Wasting among Children Aged 5 and Under in Western Kenya. J Trop Pediatr [Internet]. 2004 Oct 1; 50(5):260-70. Available from: https://academic.oup.com/tropej/articlelookup/doi/10.1093/tropej/50.5.260

31. Rakotomanana H, Gates GE, Hildebrand D, Stoecker BJ. Determinants of Stunting in Children under 5 Years in Madagascar. Matern Child Nutr. [Internet]. 2017 Oct 28; 13(4). Available from: https:// onlinelibrary.wiley.com/doi/abs/10.1111/ mcn.12409.Semba RD, De Pee S, Berger SG, Martini E, Ricks MO, Bloem MW. Malnutrition and Infectious Disease Morbidity among Children Missed by the Childhood Immunization Program in Indonesia. Southeast Asian J Trop Med Public Health. 2007; 38(1):120-9.

33. Bothwell $\mathrm{TH}$. Iron Requirements in Pregnancy and Strategies to Meet Them. Am J Clin Nutr. 2000; 72(1):257S-264S.

34. Scholl TO. Maternal Iron Status: Relation to Fetal Growth, Length of Gestation, and Iron Endowment of the Neonate. Nutr Rev [Internet]. 2011 Nov; 69:S23-9. Available from: https://academic.oup.com/ nutritionreviews/article-lookup/ doi/10.1111/j.1753-4887.2011.00429.x 
35. Aryastami NK, Shankar A, Kusumawardani $N$, Besral $B$, Jahari $A B$, Achadi E. Low Birth Weight was the Most Dominant Predictor Associated with Stunting among Children Aged 1223 Months in Indonesia. BMC Nutr [Internet]. 2017 Dec 7; 3(1):16. Available from: http://bmcnutr.biomedcentral.com/ articles/10.1186/s40795-017-0130-x.

36. Haider BA, Olofin I, Wang M, Spiegelman D, Ezzati M, Fawzi WW. Anaemia, Prenatal Iron Use, and Risk of Adverse Pregnancy Outcomes: Systematic Review and Meta-Analysis. BMJ [Internet]. 2013 Jun 21; 346:f3443f3443. Available from: http:// www.bmj.com/cgi/doi/10.1136/bmj.f3443.

37. Nisar Y, Dibley M, Aguayo V. Iron-Folic Acid Supplementation during Pregnancy Reduces the Risk of Stunting in Children less than 2 Years of Age: A Retrospective Cohort Study from Nepal. Nutrients. 2016; 8(2):67.

38. Kementrian Kesehatan Republik Indonesia. Profil Kesehatan Indonesia 2018 [Internet]. Jakarta: Kementerian Kesehatan Rl; 2019. Available from: https://www.kemkes.go.id/resources/ download/pusdatin/profil-kesehatan-

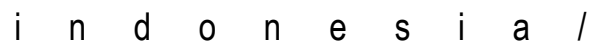
PROFIL_KESEHATAN_2018_1.pdf.
39. Laksono AD, Kusrini I. Gambaran Prevalensi Balita Stunting dan Faktor yang Berkaitan di Indonesia: Analisis Lanjut Profil Kesehatan Indonesia Tahun 2017. 2019; (March):0-12. Available from: https://www.researchgate.net/ publication/331908237.

40. Wijayanto SM. Faktor-Faktor yang Berhubungan dengan Stunting di 18 Kabupaten Provinsi Jawa Barat Tahun 2015- 2016. Institut Pertanian Bogor; 2018.

41. Stewart $\mathrm{CP}$, lannotti $\mathrm{L}$, Dewey $\mathrm{KG}$, Michaelsen KF, Onyango AW. Contextualising Complementary Feeding in a Broader Framework for Stunting Prevention. Matern Child Nutr. [Internet]. 2013; 9:27-45. Available from: http:// doi.wiley.com/10.1111/mcn.12088.

42. Penny ME, Creed-Kanashiro HM, Robert RC, Narro MR, Caulfield LE, Black RE. Effectiveness of an Educational Intervention Delivered through the Health Services to Improve Nutrition in Young Children: a Cluster-Randomised Controlled Trial. Lancet [Internet]. 2005 ; 365(9474):1863-72. Available from: https://linkinghub.elsevier.com/retrieve/ pii/S0140673605664264. 